International Journal of Instruction

e-ISSN: 1308-1470 • www.e-iji.net

Article submission code:

20191114004243

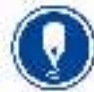

Received: $14 / 11 / 2019$

Revision: 17/09/2020
April 2021 • Vol.14, No.2

p-ISSN: 1694-609X

pp. $345-368$

Accepted: 10/10/2020

OnlineFirst: 21/01/2021

\title{
The Relationship between Personality, Attitude, and Organizational Citizenship Behavior of Senior High School Teachers in Indonesia
}

\section{Muhammad Alwi}

Correspondent author, Universitas Negeri Malang, Indonesia,muhalwi1971@ gmail.com

\section{Bambang Budi Wiyono}

Prof. Dr., Universitas Negeri Malang, Indonesia, bambang.budi.fip@um.ac.id

\section{Ibrahim Bafadal}

Prof. Dr., Universitas Negeri Malang, Indonesia, ibrahim.bafadal.fip@um.ac.id

\section{Ali Imron}

Prof. Dr., Universitas Negeri Malang, Indonesia, ali.imron.fip@um.ac.id

This research aims to determine the relationship between personality, attitude and behavior of secondary school teachers in Indonesia. Personalities include Big Five (BV), Emotional Intelligence (EI), Gender (G) and Age (A). While attitudes include Perception of Organizational Justice (POJ) and Organizational Commitment (OC) while Behavior is Organizational Citizenship Behavior (OCB). The sample is from 175 people. The results of the study showed that Personality (BV da EI) has positively related to attitude, while towards OCB, only BV was consistent, while EI will be significant to OCB if it passes POJ, while directly it is not significant. $\mathrm{G}$ and $\mathrm{A}$ are not significant to $\mathrm{OCB}$ and are inconsistent with their relationship to attitude. As well attitude has a significant relationship to behavior (OCB). Therefore, it is expected that school institutions should pay attention to teacher BV, both in recruiting, coaching and maintaining his performance. Besides that, schools need to pay attention to the school environment in order to provide good POJ, in order to increase the positive behavior of teachers in schools, besides that it is also necessary to motivate teachers (because the loading factor in the EI indicator is the lowest, 0.635 compared to the others).

Keywords: trait, organizational justice, commitment, citizenship behaviour, teachers

\section{INTRODUCTION}

Many experts have made organizational citizenship behavior (OCB) related themes the primary focal points of their studies in the past decade. As an illustration, during the last 3 years, OCB research has emphasized, for example, in relation to hospitals (Tuan, 2019, Jahani et al., 2018), IT Professionals (Jolanta, 2018), nursing profession (Yu et

Citation: Alwi, M., Wiyono, B. B., Bafadal, I., \& Imron, A. (2021). The Relationship between Personality, Attitude, and Organizational Citizenship Behavior of Senior High School Teachers in Indonesia. International Journal of Instruction, 14(2), 345-368. https://doi.org/10.29333/iji.2021.14220a 
al., 2018), construction project (Lim \& Martin, 2017), and educational institutions (Akturan \& Hulya, 2016, Parul, A, 2018, Nur Farhah \& Fatimah, 2018, Cordeiro et al, 2019). Generally, such studies are conducted in many aspects from theoretical until applicative aspects.

Various studies on OCB, so far, have examined many aspects of the influence of several factors on OCB. For example, some researchers reported that OCB was influenced by personality and mental or mood conditions (George \& Brief, 1992, Suci et al, 2018, Mortaza \& Carol, 2019, Chandrasekara 2019), while Wayne et al. (1997) has reported the quality of superior-subordinate relations with OCB (1997), and its correlation to tenure has been reported by Sommers et al. (1996), and to gender (Lovell et al. 1999, Alizadeh 2012, Riffat-un-Nisa et al. 2018, Riana. S et al. 2018). The relationship of perceptions of organizational support and organizational justice towards OCB was studied by Liden et al. (1996), Wayne, et al. (1997), Moorman, et al. (1998), and Shapiro et al. (2002), Alizadeh (2012), the correlation of perception to the organizational climate, procedural justice and was carried out by Schappe (1998) and Moorman (1991), and Dipaola (2001). Thus, it is significant to study OCB more comprehensively, by looking at the various factors that influence it.

Moorman \& Blakely (1995, Purba, 2004) stated that individuals who had high collectivistic values (Big Five) tended to create high OCB. One of the factors forming OCN is personality as the result of research undertaken by Sambung et al. (2012). Moreover, Organ (1990), Sambung \& Iring (2014) argued that the individual's difference was a predictor playing a key role in the individuals so that they would show their OCB. The recent studies also revealed the similar result like those conducted by Zhou Jiang, et.al. (2017), Saraih, et al. (2017), Pooja et al (2019), Erna, et al. (2019).

Psychologically, people who have emotional stability (EI) will feel more optimistic about their ability to achieve goals, improve creativity, and decision-making skills, and be helpful Goleman (1997, 2013), Alwi (2011), Alizadeh (2012), Neal et al. (2016), Chao et al. (2019), Turnipseed (2018), Willis (2018).

Laschinger (2003) addressed that attitude in an organization is realized in the form of organizational commitment and trust to an organization. Such trust is perceived from perception as an interpretation of the organized message (Gibson et al., 1992). Organizational justice is an individual's perception and reaction to justice in an organization (Greenberg, 1986) regarding the decision and decision-making process or others (Colquitt et al., 2001). Luthans (2011) explained that procedural justice significantly influenced OCB as stated by (Fatdina, 2007; Widyaningrum, 2009; Schappe, 1998; Zhou et al., 2017), the organizational justice positively influenced OCB (Paramitha, 2014; Khalid et al., 2014).

However, the other researchers found that procedural justice did not significantly affect OCB (Sabran et al., 2008). The other research published by Sjahruddin (2013) and Batool (2013), Bayu \& Sudarma (2015) reported that organizational justice did not significantly impact on OCB. In another side, Kreitner \& Kinicki (2005), Siti \& Harnoto 
(2018), Erna et al. (2019), stated that the better procedural justice felt by employees would improve their organizational commitment.

Meanwhile, research related to organizational commitment was carried out by Carson \& Carson (1998), Morrison (1994), Organ (1990), Puffer (1987), O’Reilly \& Chatman (1986), Bateman \& Organ (1983), Kaihatu \& Rini (2007), Akar, H. (2018). Elizabeth \& Salim (2018), Zhou et al (2017), Cordeiro et al (2019), empirically showed that organizational commitment significantly influenced OCB. However, the other researchers also found the contrary result that organizational commitment did not considerably affect OCB like the study undertaken by Kaihatu \& Rini (2007), and SuYung Fu (2000).

Although research on OCB have been carried out quite a lot in the last few decades, studies related to the teachers are still rarely conducted. Regarding education, OCB research is very crucial to develop because education is unique and different compared to other fields such as health or industry and business. In this case, teachers have an extremely essential job in deciding the progression or debacle of education at all levels and structures. Therefore, educational institutions need teachers who are highly committed, ready to help students as well as other coworkers. Teachers are also required always to be able and prepared to carry out other additional responsibilities.

A study conducted by DiPaola \& Neves (2009) revealed that the OCB behavior of the teacher in public schools in the United States and Portugal affected organizational effectiveness. Zeinabadi (2011) that examined OCB and teachers at the school said that procedural justice had two pathways to promote teacher's OCB. First, it is through influencing teacher's trust and the second is affecting teacher's OCB through job satisfaction and organizational commitment. Likewise, Soner (2009) conducted a study related to teachers' OCB in Turkey and Bogler \& Anit (2015) studied the teachers in Israel in regards to the connection between support in dynamic and OCB behavior. Rahmi (2013), Kaihatu \& Rini (2007) examined the Senior High Schools in Indonesia and Makvandi et al. (2017) studied the relationship between organizational commitment, motivation, and OCB, the teachers in Iran, also in the last years, Akar (2018), Meyer, et al. (2019), Riffat-un-Nisa et al. (2018) in Pakistan, Parul (2018), Chandrasekara (2019), in Sri Lanka, Nur Farhah \& Fatimah (2018) and Choong Yuen Onn, et al. (2018), in Malaysia. Unfortunately, those studies have not more fully and sequentially examined how the relation of self-sufficient factors (personality) (such as Gender, Age, Emotional Intelligence and Big Five, etc.) to attitudes (here is Perception of Organizational Justice and Organizational Commitment) towards behavior (OCB). Personality and emotions provided a lot of important information about a person's and interpersonal transactions with an organization (Lazarus, 1991), besides, seeing the individual's emotions of individuals in the organization would provide rich information about organizational strategies (Matthews et al., 2004), Schutte \& Malouff, (2011). Meanwhile, Azwar (2007) stated that psychologically, there are stages in behavior namely internal factors (personality) that will determine attitudes, and someone's attitudes will determine their behavior. Therefore, a more comprehensive study that links various factors that 
influence OCB behavior, and behavioral stages in the form of personality and attitude factors, is necessary.

Regarding the importance of a comprehensive study of the relationship between the teacher's personality, attitudes, and behavior, of Indonesia has unique characteristics that are not shared by other countries, especially the large population. The latest official government data, the number of high schools in Indonesia is 12,689, with the number of teachers as many as 283,223 teachers spread in 35 Provinces (BPS, 2016). The high school level is significant because this period is the stage towards the world of higher education and the work. Therefore, in this study, it was reported that the relationship between personality which included (Big Five, EI, Gender and Age) was expected to produce attitudes in the form (perceptions of organizational justice and organizational commitment) and their relationship to OCB behavior. Interestingly, this research directly examined a number of these factors for OCB and indirectly examined them through variables such as perceptions of Organizational Justice and Organizational Commitment.

\section{LITERATURE REVIEW}

\section{OCB}

OCB is an individual's behavior that tends to help and that behavior is not included in the formal standard description of their work (Organ, 1990, Kidwell et al, 1997; Jahagir et al, 2004). The behavior is voluntary, not included in the work requirements, it is a personal choice (Podsakoff et al. 2000, Ahdiyana, 2004), a positive and constructive social behavior (Kaihatu, 2007). Several dimensions of OCB, according to Marshall (1950 in Vigoda \& Golembiewski (2001), Bolino, et al (2002), and Adhiyana (2004) have 3 main elements, namely obedience, loyalty and participation. According to Organ (1988) and Saptoani (2011), OCB has five aspects, namely: 1) Altruism, helping behavior that is intentionally carried out by someone within an organization, related to other tasks or problems; 2) Conscientiousness, related to timeliness, having better presence, wise in following company regulations; 3) Courtesy, to be aware and respectful of the rights of others; 4) Sportsmanship, related to behaviors such as avoiding small complaints, gossiping, and exaggerating problems; 5) Civil Virtue, responsible participation in policies of the organization.

OCB measurements are much sought as in Bateman and Organ's (1983) studies (in Turnipseed and Murkison (1996), in which they developed 30 question items. In Paola and Tschannen-Moran's study $(2001,2003)$, they developed one specifically for schools as a modification of Smith's et al. (1983) model, measured by the Five Point Scale (a five-point) or Likert Scale (Kaihatu, 2007).

The Big Five

Personality is defined as the overall way individuals respond and communicate with others (Robbins \& Judge, 2008: 127). The number of personality traits and personality scales varies greatly (Goldberg in John \& Srivastava, 1999). There are many concepts of personality, but in the past 20 years, two approaches are widely used, besides being able 
to embrace the personality dimension it also provides practical guidance and can be used in making organizational management decisions. The two are the Myers-Briggs Type Indicator (MBTI) and the Big Five Model. Robbin said, the Big Five has more support and is more valid than the MBTI (Robbin, 2008: 132).

Dimensions of the Big Five Personality are: 1) Openness to New Experience (O), 2) Conscientiousness (C), 3) Extraversion (E), 4) Agreeableness (A), 5) Neuroticism (N) (Pervin, 2005).

The Big Five Personality measurement includes the Big Five Inventory (BFI), consisting of 44 items developed by John (1990), IPIP consisting of 50 items (Goldberg, 1992). There is also a shortened version, NEO PI-R/FFI (Costa \& McCrae, 1995). In a study using the BFI (Big Five Inventory) approach, 25 items were used from the researchers' modification of the items above.

Organizational Commitment

Organizational commitment is a feeling and attitude held by an employee corresponding to the organization he works in (Riggio, 2008). It can also be identified as the circumstances in which an employee favors an organization and its objectives, plans to keep up participation or their enrollment (Robbins, 2001; Durkin \& Bennet, 1999; Curtis \& Wright, 2001; Jenifer \& Gareth, 2002; Kreitner \& Kinicki, 2005). An employee who has a good organizational commitment will be loyal, be seriously involved and make efforts for the good of the organization. Organizational commitment brings positive results such as high performance, low turnover rates and low absence rates (Luthans, 2006 in Rahmi, 2013). Many factors affect organizational commitment such as personality, job characteristics, work experience, age, gender, years of service (John \& Taylor, 1999; Allen and Meyer, 1991 in Sopiah, 2008: 163-164).

Dimensions of Organizational Commitment

The dimensions of organizational commitment are introduced by many, such as Luthans (2006), Mowday, et al (1982 in Wulandari, 2015). However, the ones which are quite popular and widely used are from Tett and Meyer (1993), Meyer et al. (2002), Karakus and Aslan (2008), Aydogdu and Asikgil (2011). They suggested three dimensions of organizational commitment, namely 1) affective commitment: emotional connection, identification and employee involvement in an organization. 2) Continuance commitment, they will feel loss if they have to leave the organization, because they have invested enough in both energy and time. 3) normative commitment, they feel obliged and there is a necessity for them to stay there, because of value or otherwise (Meyer \& Allen, 1991).

Perception of Organizational Justice

Perception is the experience about a subject, event, or relationship obtained by gathering information and interpreting messages (Rachmat, 1985; Mitchel, 1982; Gibson et al., 1992; Luthans 2006). Organizational justice is the individuals' perception of and reaction to justice in an organization. These perceptions include matters regarding the 
fairness of decisions, decision making processes in organizations, and the influence of perceptions on behavior (Colquitt et al., 2001). Greenberg (1986) asserted that "what is fair is what brings about good for all". Lee et al (1999) stated that organizational justice is an evaluative appraisal of the suitability of the treatment of others. Organizational justice isn't a verifiable factor, more so an employee's impression of the organization (Beugre, 1998; Folger \& Cropanzano, 1998). Many factors influence perceptions, such as experience, motivation, (Allport, 1955; Lerner, 1975), and personality (Norman, 1953; Maslow \& Block, 1957; Rahmat, 1986).

Dimensions of Organizational Justice

Deustch (1985), Tornblom (1992), Beugrè (2002), Erdogan (2002), Spangenberg et al., (2001), and Damayanti (2003) mention three dimensions of organizational justice. 1) Distributive Justice, justice that a person receives as a result from allocation decisions, for example, salary standards. 2) Procedural Justice: Laventhal (1976) and Thibault \& Walker (1975) state that justice is perceived as an allocation, for example, how a salary determination process is taken, whether it's fair or not. 3) Interactional Justice: Biacs (1987) and Bies \& Moag (1986) state it as justice regarding the decision maker's interactional treatment of subordinates or employees (Cropanzano et al., 2000). In general, justice is described as a social situation when norms regarding rights and eligibility are met (Lind \& Tyler, 1988).

Emotional Intelligence (EI)

Peter Salovey and Jack Mayer define EI as the capacity to perceive sentiments, reach and bring out emotions to enable the mind, to comprehend their feelings and implications, control those feelings inside and out so as to help emotional and intellectual development. Bar-On (in Stein, 2003: 30; Modasir \& Singh, 2008) argues that EI is a series of abilities, competencies, and non-cognitive skills which affect one's ability to successfully cope with environmental demands and pressures. Gottman (1999: 2) explains that EI is about being aware of feelings, being able to empathize, control impulses, delay gratification, motivate yourself, and read other people's social cues. In general, it can be concluded that emotional intelligence is an ability possessed by an individual to be able to use their feelings optimally to recognize themselves and the surrounding environment. It is emotional intelligence that motivates us to seek our unique benefits and potential, also activate our deepest aspirations and values, changing them from what we think to what we live.

Dimensions of Emotional Intelligence (EI) According to Daniel Goleman

Generally, the dimension of Emotional Intelligence (EI) according to Daniel Goleman is divided into two, namely Personal Competence and Social Competence. Both of these generate 5 important points related to an individual's Emotional Intelligence.

Personal Competence is the ability to determine how we manage ourselves. It consists of 1) Self Awareness, which includes emotional awareness, self-assessment, selfconfidence; 2) Self Control which includes Self Control, Trustworthiness, Vigilance, Adaptability, and Innovation. 3) Self-motivation: includes encouragement of Achievement, Commitment, Initiative, and optimism. 
Social Competence is the ability to handle relationships. It consists of 4) Empathy, which includes points such as understanding others, service orientation, developing others, overcoming diversity, and political awareness. 5) Social skills: capabilities related to influence, communication, leadership, change catalysts, network binding, collaboration and cooperation, and team capabilities (Goleman, 2003: 42-43).

Gender and Age

Gender and age are considered because this is a factor that remains irreversible and influences the behavior of many of the variables above, ranging from OCB, the Big Five, organizational commitment, perceived organizational justice to emotional intelligence (although with a variety of different studies). There are findings that claim that there is an influence, others claim otherwise.

\section{METHOD}

This research was conducted in Pasuruan regency, Indonesia. Pasuruan consists of 24 districts which are divided into 341 desa (villages) and 24 kelurahan (subdistrict/urban communities) with Bangil as the capital. There are 43 high schools with approximately 1,162 teachers (Department of National Education's Data, 2017). This study uses the quantitative approach, specifically the non-experimental correlational descriptive design using surveys (Kerlinger, 1986; Creswell 2009). This study aims to determine the variables that influence (independent) and variables that are the results (dependent) and determine the nature of the independent variable and the expected effect.

Table 1

The Variable, Dimension and Questionnaire

\begin{tabular}{|c|c|c|c|}
\hline No & Variable & Dimension & Questionnaire \\
\hline 1 & OCB (Organ) & $\begin{array}{l}\text { Altruism (OCB1), Courtesy (OCB2), } \\
\text { Sportsmanship (OCB3), } \\
\text { Conscientiousness (OCB4), Civic Virtue } \\
\text { (OCB5) }\end{array}$ & $\begin{array}{l}\text { Adapted from DiPaola \& } \\
\text { Tschannen-Moran (2003), Smith } \\
\text { et al. } \text { (1983), Kaihatu \& Rini } \\
\text { (2007). }\end{array}$ \\
\hline 2 & $\begin{array}{l}\text { Big Five (McCrae \& } \\
\text { Costa) }\end{array}$ & $\begin{array}{l}\text { Extraversion (BV1), Agreeableness (BV2), } \\
\text { Conscientiousness (BV3), } \\
\text { Neuroticism (BV4), Openness to New } \\
\text { Experience (BV5), Self-Awareness (BV6) }\end{array}$ & $\begin{array}{l}\text { Adapted from BFI (Big Five } \\
\text { Inventory), John et al. (1991) }\end{array}$ \\
\hline 3 & EI (Goleman) & $\begin{array}{l}\text { Self-Awareness (EI1), Self Control (EI2), } \\
\text { Self-Motivation (EI3), Empathy (E14), Social } \\
\text { Skill (EI5). }\end{array}$ & $\begin{array}{l}\text { Adapted from Emotional } \\
\text { Competence Index (ECI) from } \\
\text { Goleman (Shields \& Warner, } \\
\text { 2007, Septoani 2011). }\end{array}$ \\
\hline 4 & $\begin{array}{l}\text { Organizational } \\
\text { Commitment } \\
\text { (Meyer) }\end{array}$ & $\begin{array}{l}\text { Affective Commitment (OC1), Continuance } \\
\text { Commitment (OC2), Normative Commitment } \\
\text { (OC3) }\end{array}$ & $\begin{array}{l}\text { Adapted from Meyer \& Allen } \\
(1991,1993 \text {, and 1997, 2002) }\end{array}$ \\
\hline 5 & $\begin{array}{l}\text { Perception of } \\
\text { Organizational Justice } \\
\text { (Deutsch \& Tornblom). }\end{array}$ & $\begin{array}{l}\text { Distributive Justice (POJ1), Procedural } \\
\text { Justice (POJ2), Interactional Justice (POJ3) }\end{array}$ & $\begin{array}{l}\text { Adapted from Deutsch (1985) \& } \\
\text { Tornblom (1992), Colquit } \\
\text { (2001). }\end{array}$ \\
\hline $\begin{array}{l}\text { Note: } \\
\text { OCB } \\
\text { (Sport } \\
\text { Emotic } \\
\text { (Empa } \\
\text { Distrib } \\
\text { Justice }\end{array}$ & $\begin{array}{l}\text { (Organizational Cit } \\
\text { manship), OCB4 (C } \\
\text { onal Intelligence), E } \\
\text { thy), EI5 (Social Sk } \\
\text { outive Justice), POJ2 } \\
\text { ). OC (Organizatior }\end{array}$ & $\begin{array}{l}\text { enship Behavior), OCB1 (Althruism), } \\
\text { nscientiusness), OCB5 (Civic Virtue). } \\
\text { (Self -Awereness), EI2 (Self-Control), } \\
\text { l). POJ (Perception of Organizational J } \\
\text { Perception of Procedural Justice), POJ3 } \\
\text { l Commitment), OC1 (Affective Comn }\end{array}$ & $\begin{array}{l}\text { OCB2 (Courtesy), OCB3 } \\
\text { EI (Emotional Intelligence, } \\
\text { EI3 (Self-Motivation), EI4 } \\
\text { ustice), POJ1 (Perception of } \\
\text { (Perception of Interactional } \\
\text { nitment), OC2 (Continuance }\end{array}$ \\
\hline
\end{tabular}


Commitment), OC3 (Normative Commitment). BV (Big Five), BV1 (Extraversion), BV2 (Agreeableness), BV3 (Contientiousness), BV4 (Neuroticism), BV5 (Openness to New Experience).

With several considerations (area, representation, population and sample size), samples were selected based on proportionate stratified simple random cluster sampling. Data is taken based on the selection of subdistricts. This selection is based on representation and distribution of subdistricts in Pasuruan Regency. Preliminary research results indicate that there are 5 districts namely Bangil, Beji, Purwosari, Pandaan and Prigen with a total of 22 schools (out of 43 schools) and 677 teachers. After calculating the population representation by Gay (Umar, 2001), 175 high school teachers (out of 677 as mentioned earlier) were selected as samples from a proportional number of men and women in each district. This study used a questionnaire which was adapted from experts as mentioned in the table above. It was modified with approval and validation which was done with a pre-test of 30 people using Pearson correlation (Product Moment) $r>$ 0.3 (Sugiono, 2001) and Cronbach's Alpha reliability test $\geq 0.6$. The questionnaire utilizes the Likert scale scoring from 1 to 5 , where 1 means firmly differ or 'strongly disagree' and 5 is unequivocally concur or 'strongly agree' with the favorable and unfavorable points. Inferential analysis was completed using SPSS 22 Statistics, Structural Equation Modeling (SEM), and Partial Least Square (PLS).

\section{FINDINGS}

Out of 175 respondents, the frequency of the male was 94 people $(53.7 \%)$, and the female was 81 people $(46.3 \%)$. Regarding the frequency of age description data, the age under 30 years old was 51 people $(29.1 \%)$, the age of $31-40$ years old was 89 people $(50.9 \%)$; this category of age was the most significant number of frequency. Among 175 respondents, the frequency of 94 men $(53.7 \%)$ and 81 women $(46.3 \%)$ was obtained. Regarding the frequency of age description data, the respondents who had the age less than 30 years old were 51 people $(29.1 \%)$, the age of 31-40years old were 89 people $(50.9 \%)$, this age category was the highest frequency number. The respondents who had the age of 41-50 years old were 32 people (18.3\%); those who had the age above 50 years old were only three people $(1.7 \%)$. This case showed that the teacher-respondents were generally categorized as young, productive, and energic teachers.

Table 2

The description of research variable

\begin{tabular}{llllll}
\hline Criteria & EI & OC & OCB & BV & POJ \\
\hline Min & 65 & 24 & 57 & 90 & 46 \\
\hline Max & 90 & 45 & 80 & 125 & 75 \\
\hline Modus & 86 & 35 & 80 & 103 & 60 \\
\hline Mean & 81.74 & 36.95 & 71.39 & 107.76 & 63.43 \\
\hline
\end{tabular}

Based on the descriptive analysis, the variable of Emotional Intelligence had a mean of 81.74 (high). The variable of organizational commitment (OC) had a mean of 36.95 (high). The mean of the variable of OCB was 71.39 (high). Big Five (BV) had a mean of 107.76 (high). Meanwhile, the variable of Perception of Organizational Justice had a mean of 63.43 (high). Based on these results, the teacher-respondents had good enough readiness to have extra-role $(\mathrm{OCB})$ behavior. 
Table. 3

The results of test of loading factor of each research variable

\begin{tabular}{lllllllllll}
\hline Variable & BV & \multicolumn{3}{c}{ EI } & \multicolumn{3}{c}{ POJ } & OC & & OCB \\
\hline \multirow{3}{*}{ Loading } & BV1 & 0.852 & EI1 & 0.790 & POJ1 & 0.904 & OC1 & 0.898 & OCB1 & 0.735 \\
\cline { 2 - 12 } & BV2 & 0.845 & EI2 & 0.842 & & & & & OCB2 & 0.811 \\
\cline { 2 - 11 } & BV3 & 0.867 & EI3 & 0.635 & POJ2 & 0.920 & OC2 & 0.849 & OCB3 & 0.859 \\
\cline { 2 - 11 } & Bv4 & 0.879 & EI4 & 0.867 & & & & & OCB4 & 0.802 \\
\cline { 2 - 11 } & Bv4 & 0.824 & EI5 & 0.702 & POJ3 & 0.921 & OC3 & 0.905 & OCB5 & 0.800 \\
\hline
\end{tabular}

The measurement model revealed that loading factors of all indicators were highly correlated. The Big Fives were BV1 of 0.852 , BV2 of 0.845 , BV3 of 0.867 , BV4 of 0.879 , and BV5 of 0.824 . This case means that the diversity of BV variable was explained by the variable of BV1 (extraversion) of $85.2 \%$, BV2 (agreeableness) of $85.5 \%$, and also OCB (OCB 1 to OCB5), and so forth. The test of validity was done by convergent validity, by looking at the loading factor, AVE (Average Variance Extracted) $>0.5$, and Communality $>0.9$ and discriminant validity, by looking at the cross-correlation all of which were of good value. Meanwhile, to see reliability used reliability composite (>0.85) and Cronbach's Alpha (>0.8), (see table 4).

Table 4

The results of the test of validity and reliability

\begin{tabular}{lllll}
\hline Variable & AVE & Commonality & Composite Reliability & Cronbach's Alpha \\
\hline BV & 0.729 & 0.729 & 0.931 & 0.907 \\
\hline EI & 0.596 & 0.596 & 0.879 & 0.836 \\
\hline OC & 0.782 & 0.782 & 0.915 & 0.860 \\
\hline OCB & 0.644 & 0.644 & 0.900 & 0.862 \\
\hline POJ & 0.837 & 0.837 & 0.939 & 0.903 \\
\hline
\end{tabular}

Table 5

Summary of the results of the relationship between direct or indirect research variables

\begin{tabular}{|c|c|c|c|c|c|c|c|c|}
\hline Exogen & Mediation 1 & Mediation 2 & Mediation 3 & Endogen & direct & Indirect & Sig & Total \\
\hline $\mathrm{G}$ & & & & BV & 0.065 & & & 0.065 \\
\hline $\mathrm{G}$ & & & & EI & 0.076 & & & 0.076 \\
\hline \multirow{2}{*}{ G } & $\mathrm{BV}$ & & & \multirow{2}{*}{ POJ } & \multirow{2}{*}{0.043} & 0.004 & & \multirow{2}{*}{0.082} \\
\hline & EI & & & & & 0.035 & & \\
\hline \multirow{2}{*}{ G } & BV & POJ & & \multirow{2}{*}{$\mathrm{OC}$} & \multirow{2}{*}{$0.109 *$} & 0.006 & & \multirow{2}{*}{0.118} \\
\hline & EI & POJ & & & & 0.003 & & \\
\hline \multirow{2}{*}{ G } & $\mathrm{BV}$ & POJ & $\mathrm{OC}$ & \multirow{2}{*}{ OCB } & \multirow{2}{*}{0.058} & 0.002 & & \multirow{2}{*}{0.061} \\
\hline & EI & POJ & $\mathrm{OC}$ & & & 0.001 & & \\
\hline Age & & & & BV & 0.088 & & & 0.088 \\
\hline Age & & & & EI & 0.021 & & & 0.021 \\
\hline \multirow{2}{*}{ Age } & BV & & & \multirow{2}{*}{ POJ } & \multirow{2}{*}{$0.156^{*}$} & 0.041 & & \multirow{2}{*}{0.200} \\
\hline & EI & & & & & 0.003 & & \\
\hline \multirow{2}{*}{ Age } & $\mathrm{BV}$ & POJ & & \multirow{2}{*}{$\mathrm{OC}$} & \multirow{2}{*}{$0.152^{*}$} & 0.009 & & \multirow{2}{*}{0.161} \\
\hline & EI & POJ & & & & 0.001 & & \\
\hline \multirow{2}{*}{ Age } & $\mathrm{BV}$ & POJ & $\mathrm{OC}$ & \multirow{2}{*}{ OCB } & \multirow{2}{*}{-0.003} & 0.002 & & \multirow{2}{*}{0.000} \\
\hline & EI & POJ & $\mathrm{OC}$ & & & 0.000 & & \\
\hline BV & & & & POJ & $0.461 *$ & & Sig & 0.461 \\
\hline $\mathrm{BV}$ & POJ & & & $\mathrm{OC}$ & $0.310^{*}$ & $0.099 *$ & Sig & 0.409 \\
\hline \multirow{2}{*}{ BV } & POJ & & & \multirow{2}{*}{ OCB } & \multirow{2}{*}{$0.223^{*}$} & $0.119^{*}$ & Sig & \multirow{2}{*}{0.369} \\
\hline & POJ & $\mathrm{OC}$ & & & & $0.028^{*}$ & Sig & \\
\hline EI & & & & POJ & $0.160 *$ & & & 0.160 \\
\hline EI & POJ & & & $\mathrm{OC}$ & $0.166^{*}$ & 0.034 & & 0.200 \\
\hline
\end{tabular}




\begin{tabular}{llllllll}
\hline \multirow{2}{*}{ EI } & POJ & \multirow{2}{*}{ OCB } & & \multirow{2}{*}{0.093} & \multicolumn{2}{c}{$0.041^{*}$} & \multicolumn{2}{c}{ Sig } & \multirow{2}{*}{0.144} \\
\cline { 2 - 5 } & POJ & OC & OC & $0.014^{*}$ & & 0.214 \\
\hline POJ & & OCB & $0.258^{*}$ & $0.060^{*}$ & Sig & 0.318 \\
\hline POJ & OC & & OCB & $0.280^{*}$ & & Sig & 0.280 \\
\hline OC & & &
\end{tabular}

Note $^{*}=$ Significant, with the significant level of T Statistics $>1.96(\boldsymbol{\alpha}=\mathbf{0 . 0 5})$.

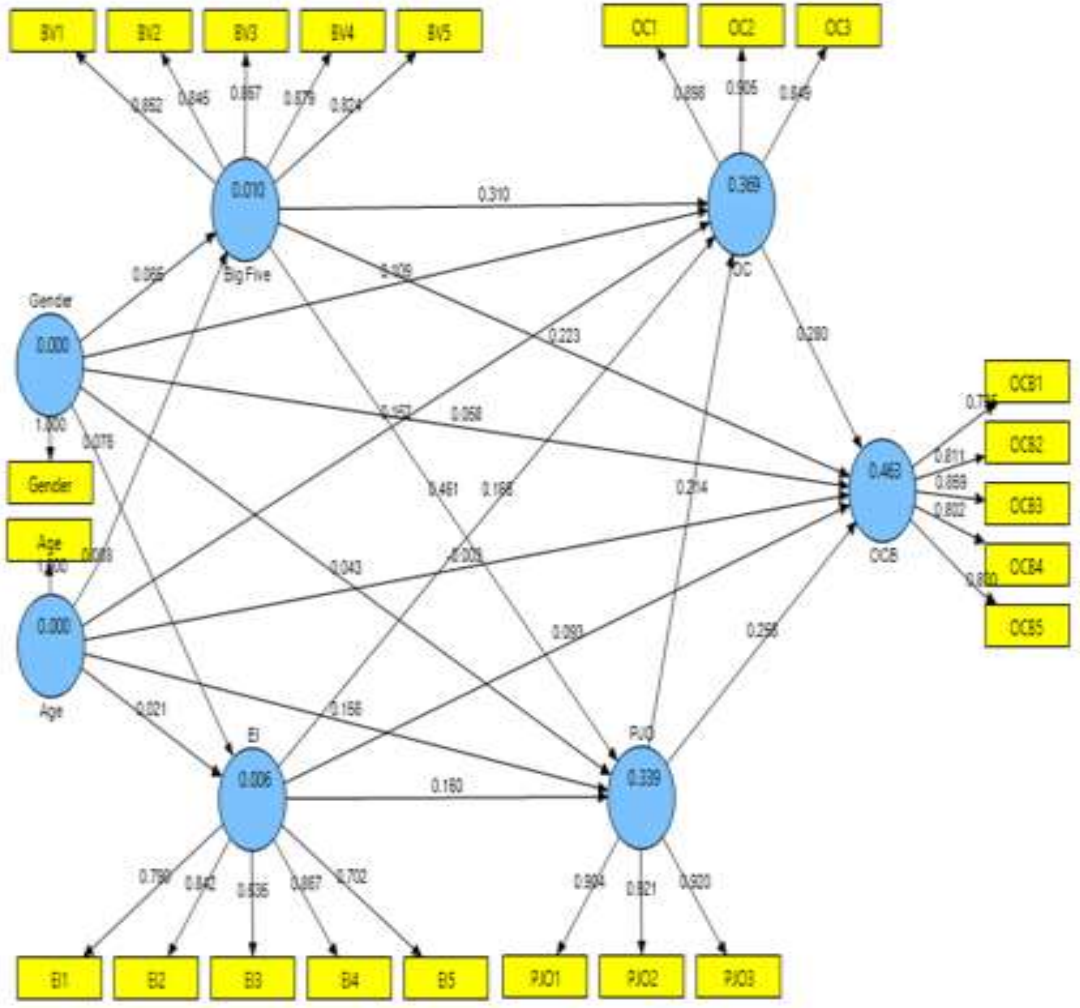

Figure 1

Path analysis of research variable

From the results above we see that almost all relationships of Gender $(G)$ produced a non-significant relationship, except G with OC. Although Age gave significant value to OC (Organizational Commitment) and Perception of Organizational Justice, it did not have a considerable impact on OCB. EI had a positive effect on OC and POJ, but it did not have a significant impact on OCB.

BV generally had a positive effect on OC and POJ, as well as OCB. The correlation of BV and POJ was significant, BV - OC (significant), BV - OCB (Significant), BV - POJ - OCB (Significant), BV - OC - OCB (Significant) and BV - POJ -OC - OCB 
(Significant). Meanwhile, POs - OC - OCB (POJ - OC, OC - OCB, POJ - OCB), all were significant. This case met the theory. When Perception of Organizational Justice was high, it would stimulate Commitment (POJ - OC), and Organizational Commitment would encourage OCB (OC - OCB) behavior. This case means that OCB would increase if OC increased and this was due to the increasing POJ and increasing BV (High). EI OC was significant; EI - POJ - OCB was significant, EI - POJ - OC - OCB was not significant.

Table 6

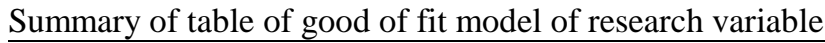

\begin{tabular}{ll}
\hline Latent Variable & R Square \\
\hline Big Five & 0.010 \\
\hline Emotional Intelligence & 0.006 \\
\hline Organizational Commitment & 0.369 \\
\hline $\mathrm{OCB}$ & 0.463 \\
\hline Perception of Organizational Justice & 0.339 \\
\hline $\mathrm{Q}^{2}=1-\left(1-\mathrm{R}_{1}{ }^{2}\right)\left(1-\mathrm{R}_{2}{ }^{2}\right)\left(1-\mathrm{R}_{3}{ }^{2}\right)\left(1-\mathrm{R}_{4}{ }^{2}\right)\left(1-\mathrm{R}_{5}{ }^{2}\right) \rightarrow$ & \\
$\mathrm{Q}^{2}=1-(1-0.010)(1-0.006)(1-0.369)(1-0.463)(1-0.339)=0.779$ & \\
\hline
\end{tabular}

The R-square of OC variable was 0.369 or $36.9 \%$, meaning that the diversity of Organizational Commitment variables was explained by the variable of BV, EI, G, POJ, and Age by $36.9 \%$ ' the remaining $63.1 \%$ was the contribution of other variables that were not discussed in this study, POJ (0.339) and OCB (0.463). The Q-Square predictive relevance was 0.779 or $77.9 \%$. This case showed that the diversity of OCB variables could be explained by the overall model by $77.9 \%$, while the remaining $22.1 \%$ was the contribution of other variables that were not discussed in this study (Table 5).

\section{DISCUSSION}

\section{The Influence of Gender, Age, and Attitude on OCB}

Table 4 presents men had more potential to commit and do OCB than women, even though the relationship was not significant. Besides that, although Age (A) gave significant values for OC and POJ, it did not have a substantial impact on OCB. Gender stereotypes occurred quite a lot including in the work environment and the behavior of OCB organizations. The results of whether Gender affected OCB were not always consistent. Beauregard (2012) stated that women are expected to do OCB as a routine part of their work, Farrell \& Finkelstein (2007) reported that women are often considered to have a higher OCB level than men. However, in another study conducted by Jafari \& Bidarian (2012), it did not affect; the one that influenced was that if their POJs were good at the organization, they caused OCB. Also, Geiger \& Geiger (2018) reported that Gender was stuck on OCB if it passed or was mediated by OJPs. Meanwhile, the other studies carried out Age and Gender on OCB, as revealed by Akinbode (2011), Jafari \& Bidarian (2012), Cameron (2013), Dewi \& Perdhana (2016) stated that demographic variables (Gender and Age) were not necessarily valid as OCB predictors, and did not have a correlation with OCB. For Age variables on OCB, it was proposed not to see the Age was but the duration of working (because this case would 
have a different impact). Those cases were possible because the era is quite modern so that the teacher's bias and professional boundaries have no significant effect on men or women.

\section{The Influence of Personality on Attitude}

In general, personality (BV, EI, G, and A) is positively related to OC, but not to POJ (except $\mathrm{U}, \mathrm{BV}$ and $\mathrm{EI}$ ). The better the personality and emotion (BV and EI) of a person would have an impact on how they perceived and interpreted it in an organized manner against the incoming stimulus (Gibson et al., 1992). Perception is influenced by personal factors, personality, and so on (Rahmat, 1986: 64). This case is following Colquitt et al. (2001) stated that personality would affect POJ which was the individual's perception of organizational behavior in the form of distribution, procedural, and interactional justice in the organization.

When organizations provide employees with what is promised and valued by them, employees will respond in the form of positive attitudes and behaviors (commitment, job satisfaction, no intention to leave the organization and ordinary behavior). They will also side with the organization and its objectives and intend to survive and maintain membership and help an organization to achieve its goals (OC). This case is also in accordance with previous research conducted by Fatdina (2007), Ince and Gul (2011), Sjahruddin (2013), Batool (2013), Bayu \& Sudarma (2015), Bhargava (2008), and Khan et al. (2018).

OC is one of the work attitudes; it reflects a person's feelings (likes or dislikes) on the organization where he/she works. OC is also an individual's orientation towards organizations that includes loyalty, identification, and involvement, and it is an active relationship orientation between individuals and their organizations. This orientation results in individuals at their willingness to provide something in the form of support for achieving organizational goals (Robbins \& Judge, 2013).

Big Five which is a positive personality character will support someone in having attitude and behaving towards the organization. This case is in accordance with the previous ones such as Mathieu and Zajac (1990), Dunham et al., (1994), Steers (1977), who found that personality influenced organizational commitment, also Seniati (2006), Haryati (2006), Kappagoda (2013), also (Sambung \& Irving, 2014) the examined BV and OC of English teachers.

\section{The Influence of Personality on OCB}

If teachers' BV is good, in general, they will be easy to get along with, have a friendly attitude, be not easy to complain, be ready to help others and so on. All those things will have an effect on behavior in the form of willingness to consciously and voluntarily work, contribute more than the role formally demanded by the organization (OCB). This case is consistent with several previous studies conducted by George \& Brief (1992) arguing that one's willingness to help others was also influenced by mood (EI and Big Five), as well as by Barrick \& Mount (1991), stating that the BV (extraversion) dimension was the primary determinant in social behavior. Therefore, individuals with 
extraversion characters will display more flexible behaviors that make them more likely to show OCB.

Individuals with extraversion characters were more involved in OCB because they were more responsive to the social environment and more open to criticizing others (Organ et al., 2006). Conscientiousness was one of the most important personality traits in predicting OCB (Elanain, H.A, 2007, Hurtz \& Donovan 2000; Organ \& Ryan 1995; Kumar 2009). Openness was the most critical personality trait in predicting OCB (Elanain, H.A, 2007). According to Moorman \& Blakely 1995, individuals with high collectivistic values would tend to do OCB behavior. Meanwhile, Salwa \& Rinandita (2017) gave evidence that the Big Five influenced OCB from the five dimensions of his personality.

Besides, Hofstede (1991, 2004) also addressed that Indonesia respectfully values collectivism, notwithstanding the qualities of Indonesians who maintain fellowship and support (Koentjaraningrat, 1990) with its characteristics such as mutual cooperation, a social solidarity formed because of assistance from other parties, for personal interests or group interests so that there is a loyal attitude of each citizen as a whole (Sudrajat, 2014). This case will create a kind of social exchange (Blau, 1964; Fung et al., 2015), which is expected in the organization, so that they are easy to help, act outside their obligations, and work descriptions. Meanwhile, the relationship between EI and OCB was expected to produce positive and significant like the others, but it was positive but not significant (the T-Statistics was $1.594<1.96$, with direct coefficient of 0.093 ). How could this happen? Goleman, stated that EI consists of two significant competencies, namely, personal/individual and social competence. Personal competence consists of: 1) Self Awareness or mindfulness; 2) Self Control or poise, that includes a) self-control, managing emotions, and destructive heartbeat), b) Maintaining the norms of honesty and integrity, alertness, adaptability, etc; 3) Self-Motivation that includes encouragement of achievement, encouragement to be better or meet the standards of work and success), Commitment and adjustment to the target group or company), initiative and readiness to take advantage of opportunities, as well as optimism, persistence in realizing control goals from obstacles and failures. Social Competence which consists of 1) Empathy, namely understanding other people, feeling the perspective of others, and showing a spark in their hobbies, purposefully lending a hand, recognizing and trying to meet other's needs, overcoming diversity, the ability to grow opportunities with plenty of socialization, etc.; 2) Social Skills (Goleman, 2003: 42-43).

We can see that the constructors forming the EI in this study were dominated by Self Control (0.842) and Empathy (0867), while self-motivation was low that was only (0.635). It means that even though they had a good Emotional Intelligence, but intelligence was based on self-control and empathy which did not cause a significant boost to behave in organizations in the form of OCB. Ibrahim (2013) saw the contract of self-motivation was the most dominant and had the most substantial influence on EI (see also Jen Ling Gan, 2018). 2) Even though they had a high collectivity and cooperation habits that were part of the habit of helping, but this case was done not for achievement, encouragement of social exchange, the main component of OCB, but it only relied on 
the average of feeling not good if it was not together, did not want to be different or wrong (self-control) and empathy.

\section{The Influence of Personality on Behavior through Attitude}

The relationship of BV - POJ - OCB obtained a t-statistic result in 3.138 (significant and positive) with an indirect coefficient of 0.119 . The better POJ consisted of perceptions of decisions, decision-making processes, and others (Colquit et al., 2001), where the perception is a person's subjective factor (Beugre, 1988; Folger \& Cropanzano, 1988). This case was caused or influenced by people's personality (Norman, 1983; Maslow \& Block, 1957; Micheal, 1982; Grace, 1986; Shi et al., 2009, Robbin \& Judge, 2011) that would cause them to behave positively towards the organization. This behavior takes the form of willingly and voluntarily working and contributes more than the role formally demanded by the organization. This case is in line with research carried out by Schappe (1988), Widyaningrum (2009), Jafari \& Bidarian (2012), Paramitha (2014), Khalid et al. (2014), Salwa (2017), Naiemah, et al., (2017), Shah \& Halim (2018), and Chandrasekara (2019).

Meanwhile, the relationship between EI - POJ - OCB produced T-Statistics of 2.255 and the indirect coefficient of $0.041^{*}$ (Positive and Significant). EI is the individuals' ability to organize their emotions (Mayer \& Salovey, 1997). Therefore, people with high EI will be able to understand themselves, others, and their environment well, and can use their emotions to improve behavior and attitudes towards more positive, more motivated, and satisfied things, and also overcome the problems of work environment and health (Matthews et al., 2004; Wong et al., 2005; Lalatendu, 2017). EI also reduced work stress and directed high performance (Bar-On et al., 2006; Druskat et al., 2006) and organizational success (Mount, 2006). Mikolajczak et al., (2008) reported that EI helped to moderate the effects of unfair treatment or organizational injustice on individuals. With high EI, there would not be much complaining (Mayer et al., 2000), even offering help or encouragement to others. A person who had high EI tended to be compassionate (Ciarocchi et al., 2000) and easily fit in with an organizational perspective and do things for the good of the organization (Abraham, 1999). EI was related to job satisfaction and other positive behaviors in the organization (Dormann \& Zapf, 2001; Gerhart, 2005; Heller et al. 2002; Staw et al. 2005; Robbins, 2005, Bighami 2013).

With a good EI, the POJ as a perception of institutional justice in the form of distributive, procedural and interactional justice perceptions, tended to be more positive, and this would affect individual' behavior in the way of conscious and voluntary work and contribute more than the formally required role by his organization. This case is in accordance with the joint research on POJ that would influence OCB executed by Kreiner \& Kinicki (2005), Luthan (2006), Jafari \& Bidarian (2012), Paramitha (2014), Khalid (2014), Fatdina (2013), Schappe (1988), and Widyaningrum (2009). The relationship between BV - POJ - KO - OCB or the effect of Personality on OCB through Attitudes resulted in t-Statistic of 2.049 (significant and positive) with an indirect coefficient of 0.028 . POJ produced OCB $(0.258 *)$, then POJ produced KO $\left(0.214^{*}\right)$, then KO produced OCB $(0.280)$ behavior. This case is consistent with other 
studies such as Leow \& Khong (2009), Hassan (2014), Crow et al. (2011), Dehkordi et al. (2013), Suhermin, (2014), Siti \& Harnoto (2018).

When an organization was kind, the employees would respect and trust, and they would conduct social exchanges (Blau, 1964) in the form of replying to it in positive attitudes such as commitment, achieving organizational goals, and being loyal to the organization. This case is consistent with what stated by (2008), Khan et al. (2018). Besides, an attitude (OC) was influenced by personality (BV) according to the study of Leephaijaroen, S (2016), etc. Among the four personality variables (BV, EI, U, and G), it appeared that only BV which gave a consistent explanation, while EI would impact only through the POJ. BV, generally, had a positive impact on $\mathrm{KO}$ and POJ, as well as OCB. The relationship of BV - POJ was significant, BV - KO was significant, BV POJ - OCB as significant, BV - KO - OCB was significant, and BV - POJ - KO - OCB was significant.

\section{CONCLUSION}

Based on the results of this study, it can be seen that personality factors (BV and EI) were positively related to attitudes, while towards $\mathrm{OCB}$, only $\mathrm{BV}$ that was consistent (direct or indirect), while EI would be significant to OCB only when passing POJ. Meanwhile, $G$ and $U$ were not significant towards $\mathrm{OCB}$ and inconsistent concerning attitude. Also, attitude variables had a significant and positive relationship with OCB. This case showed that good teachers are those whose hearts (personality) have the attention and desire to help both students, coworkers, and other people inside and outside of school. This case happens if they find suitability in choosing a job as a teacher namely freelance, teaching and educating and being interested in the field of education and teaching, wanting to develop and practice science and to participate in teaching the Indonesian people, even though the salary obtained as a teacher is relatively small. Therefore, personality factors (BV and EI) need to be considered both in recruitment and coaching as well as maintaining teacher's performance. Besides, the school needs to motivate the teacher, since the teacher's motivation seems less with the loading factor of only EI3 (0.635). Also, the educational institutions should create an environment and atmosphere so that they can be perceived and trusted which will lead to POJ and KO, and OCB. It is proposed in subsequent studies to link OCB with the order of occurrence of behavior (in the form of individual factors, attitudes, and behavior), because in many studies linking those psychological factors and also sociological factors (social-exchange) are considered very rarely conducted.

\section{REFERENCES}

Akinbode, G. A. (2011). Demographic and dispositional characteristics as predictors of organisational citizenship behaviour, 19 (IFE PsychologIA), Afrikan Jounal Online, 19(1), 375-404.

Akar, H. (2018). The relationships between quality of work life, school alienation, burnout, affective commitment and organizational citizenship: A study on teachers. European Journal of Educational Research, 7, 169-180. 
Akturan, A. \& Hülya G. Ç. (2016). The Effects of Knowledge Sharing and Organizational Citizenship Behaviors on Creative Behaviors in Educational Institutions. Procedia - Social and Behavioral Sciences 235(2016), 342-50.

Alizadeh, Z. (2012). Antecedents and Consequences of Organisational Citizenship Behaviour (OCB), Interdisiplinary Journal of Contemporary Research in Business. Institute of Interdisciplinary Business Research, January 3/9.

Alwi, M. (2011), Anak Cerdas Bahagia dengan Pendidikan Positif, Bandung, Noura Book.

Azwar, S. (2007). Sikap Manusia, Teori dan Pegukurannya, Cet XI, Yogyakarta, Pustaka Pelajar

Barrick, M. R. Mount, M. K (1991), The Big Five Personality Dimensions and Job Performance: A Meta Analysis, Personnel Psychology, 44(1), 1-26.

Bateman, T.S. \& Organ, D.W. (1983). Job satisfaction and the good soldier: The relationship between affect and employee "citizenship." Academy of Management Journal, 26, 587- 595.

Beauregard, T. A. (2012). Perfectionism, self-efficacy and OCB: The Moderating Role of Gender. Personnel Review, 41(5), 590-608.

Batool, S. (2013). Developing Organizational Commitment and Organizational Justice to Amplify Organizational Citizenship Behavior in Banking Sector. Pakistan Journal of Commerce and Social Sciences, 7(3), 646-655.

Bayu, R., T dan Sudarma. K. (2015). Pengaruh Persepsi Dukungan Dan Keadilan Organisasi Terhadap Organization Citizen Behavior Dengan Komitmen Organisasi Sebagai Variable Intervening. Management Analysis Journal, 4(2), 142-152.

Beugre, C. (1998). Managing Fairness in Organizations. Westport, CT, Quorum Books Co.

Blau, P. (1964). Exchange and Power in Social Life. New York, Wiley.

Bogler, R \& Anit, S. (2005). Organizational Citizenship Behavior in School How Does It Relate to Participation in Decision Making? Journal of Educational Administration, 43(5), 420-438.

BPS (Badan Pusat Statistik) Indonesia (2016), Tentang Jumlah Sekolah, Guru dan Murid Sekolah Menengah (SMA) menurut Provensi seluruh Indonesia.

Cameron, S. M. (2013). Gender roles and organizational citizenship behaviors: effects on managerial evaluations. Gender in Management: An International Journal, 28, 380399. 
Chandrasekara. W. (2019). Relationship among Big Five Personality Traits, Job Performance \& Job Satisfaction: A Case of School Teachers in Sri Lanka. International Journal of Information, Business and Management, 11(2), 219-232

Chao, M., Ronald H. H., Shanshan, Q, Jeffrey, M. P. (2019). The relationship between emotional intelligence and the dark triad personality traits: A meta-analytic review. Journal of Research in Personality, 78, 189-197.

Choong Yuen Onn, Jamal Nordin bin Yunus, Hamidah binti Yusof, Krishna Moorthy \& Seow Ai Na. (2018). The mediating effect of trust on the dimensionality of organisational justice and organisational citizenship behaviour amongst teachers in Malaysia, Educational Psychology, 38(8), 1010-1031.

Colquitt, J., A. (2001). On the Dimensionality of Organizational Justice: A Construct Validation of a Measure. Journal of Applied Psychology, 86, 386 - 400.

Cordeiro, J., Cunha, P \& And Lourenço, A. A. (2019). Conflict management, commitment and organizational citizenship behaviors: empirical study in a higher education institution. International Forum on Management: Value Creationand Local Heritage, February, 1-2.

Deutsch, M. (1985). Equity, equality, and need: What determines which value will be used as the basis for distributive justice? Journal of Social Issues, 31, 137-149.

Diefendorff, J. M., Brown, D. J., Kamin, A. M., \& Lord, R. G. (2002). Examining the Roles of Job Involvement and Work Centrality in Predicting Organizational Citizenship Behaviors and Job Performance. Journal of Organizational Behavior, 23, 93-108.

Dipaola, M F \& Neves, P M. (2009). Organizational Citizenship Behaviors in American and Portuguese Public Schools. Measuring the Construct across Cultures, Journal of Educational Administration, 47(4), 490-507.

Dipaola, M, Tschannen, M \& Megan. (2001). Organizational Citizenship Behavior in Schools and Its Relationship to School Climate, Journal of School Leadership, Volume (11), September: 424-447.

Elanain, H. A (2007. Relationship Between Personality and Organizational Citizenship Behavior: Does Personality Influence Employee Citizenship? International Review of Business Research Papers, 3(4), 31- 43.

Elizabeth, D \& Salim. (2018). A Study on the Role of Organizational Commitment and Perception towards Organizational Justice and Fairness in triggering Organizational Citizenship Behavior among B School Faculty Members in Kerala, Rajagiri Management Journal, June, 12/1.

Erna, E., Heru, K, T \& Fauziyah. (2019). The Influence of Prosedural Justice and Organizational Climate on Organizational Citizenship Behavior (OCB) With Employee Engagement as a Mediator. Account and Financial Management Journal, January, $4 / 01$. 
Fatdina. (2007). Peran Dukungan Organisasi Yang Dirasakan Karyawan Sebagai Mediator Pengaruh Keadilan Prosedural Terhadap Perilaku Kewarganegaraan Organisasi. Jurnal Psikologi. 36(1), 1-17.

Farrell, S. K., \& Finkelstein, L. M. (2007). Organizational citizenship behavior and gender: Expectations and attributions for performance. North American Journal of Psychology, 9, 81-96.

Fung, N. S., Ahmad, A \& Omar, Z. (2015). Work-Family Enrichment: Its Mediating Role in the Relationships Between Workplace Support Factors and Teachers' Job Satisfaction, American Journal of Applied Sciences, 12(4), 242-253.

Gibson, J. L., Ivancevich, J. M., \& Donelly Jr, J. H. (1992). Organisasi: Perilaku, Struktur, Proses. Edisi 5. Jilid 1, Terjemahan Eli Tanya. 1992. Jakarta: Erlangga.

George, J.M. \& Brief, A.P. (1992). Feeling Good-Doing Well: A Conceptual Analysis of the Mood at Work-Organizational Spontaneity Relationship. Psychology Bulletin, 112, 310-329.

Goleman, D., Boyatzis, R. \& McKee, A. (2013). Primal Leadership: Unleashing the Power of Emotional Intelligence: Harvard Business Press

Goleman, D. (2003), Working with Emotional Intelligence, Kecerdasan Emosi untuk Mencapai Prestasi, Jakarta, Gramedia.

Goleman, D. (1997). Emational Intelligence, Terjemahan T. Hermaya, Jakarta, Gramedia.

Greenberg, J. (1986). Determinants of Perceived Fairness of Performance Evaluations. Journal of Applied Psychology, 7(2), 340-342.

Geiger, M \& Geiger, M (2018). Gender, Justice, and Trust in Supervisor: A Moderated Mediation Model Predicting OCB, Academy of Management Proceedings, 2018/1, April.

Haryati, T. (2006). Hubungan Antara Dukungan Organisasi Dan Big Five Personality Dengan Komitmen Organisasi. (Skripsi, Tidak Diterbitkan), Fakultas Psikologi, UGM, Yogyakarta.

Hassan, I. (2014). Organizational Justice and Citizenship Behavior, the Mediating Role of Trust. International Journal of Human Resource Studies. 5(1), 86-96.

Hofstede, G.H. (1991). Cultures and organizations: Software of the mind. New York: McGraw-Hill.

Hofstede, G., \& McCrae, R.R. (2004). Personality and culture revisited: Linking traits and dimensions of culture. Cross-Cultural Research, 38(1), 52-88. 
Ibrahim, 2013. Pengaruh Kecerdasan Emosional Terhadap Rganizational Citizenship Behaviord dan Dampaknya Pada Kinerja Perawat Rumah Sakit Umum Anutapura \& Rumah Sakit Undata Palu. e-Jurnal Katalogis, I(1), 136-146.

Ince, M. Gul, H. (2011). The Effect of Employees Perception of Organizational Justice on Organizational Citizenship Behavior: An Application in Turkish Public Institiution. International Journal of Business and Management, 6(6), 113-149.

Jafari, P., \& Bidarian, S. (2012). The Relationship Between Organizational Justice and Organizational Citizenship Behavior. Procedia - Social and Behavioral Sciences, 47, 1815-1820.

Jahani, M. A., Shahrbanoo, M., Fatemeh, H. R, Hosein, A. N \& Ghahraman, M. (2018). Datasets on Organizational Citizenship Behavior in the Selected Hospitals with Different Ownership. Data in Brief, 19 (August):288-92.

Jen Ling Gan \& Halimah M. Yusuf, 2018. Does Emotional Intelligence Influence Organizational Citizenship Behavior among Engineers? A Conceptual Paper. Faculty of Management. Proceedings of the International Conference on Industrial Engineering and Operations Management. Bandung, Indonesia, March: 6(8), 2235-2242.

Jolanta, K., Alicja, K \& Juho, M. (2018). Organizational citizenship behavior of IT professionals: lessons from Poland and Germany, Information Technology for Development, 25(2), 227-249.

Kaihatu, S \& Rini, W.A. (2007). Kepemimpinan Transformasional Dan Pengaruhnya Terhadap Kepuasan Atas Kualitas Kehidupan Kerja, Komitmen Organisasi, Dan Perilaku Ekstra Peran: Studi Pada Guru-Guru Smu Di Kota Surabaya. Jurnal Manajemen dan Kewirausahaan, 98(1), 49-61.

Kappagoda, U.W.M.R. Sampath. (2013). The Impact of Five - Factor Model of Personality on Organizational Commitment of English Teachers in Sri Lankan Government Schools. International Journal of Physical and Social Sciences, 3(1), 1-10.

Khalid, S. (2014). Impact of Lmx on Organizati Justice and Organizational Justice on Organizational Citizenship Behavior. International Journal of Business and Management Invention, 3(10), 21-29.

Khan, S., Jehan, N., Shaheen, S \& Ali, G. (2018). Effect of Burnout on Organizational Citizenship Behaviors: Mediating Role of Affective and Continuance Commitment, basyn Journal of Social Sciences, AICTBM-18, July.

Koentjaraningrat. (1990). Pengantar Ilmu Antropologi, Jakarta Aksara Baru.

Kreitner, K. \& Kinicki, A. 2005. Perilaku Organisasi. Terjemahan Erly Suandy, Edisi Kelima, Jakarta, Salemba Empat. 
Lalatendu, K. J \& Sajeet, P. (2018). Workplace spirituality and employee commitment: The role of emotional intelligence and organisational citizenship behaviour in Indian organisations, Journal of Enterprise Information Management, 31(3), 380-404.

Laschinger, H.K.S., Finegan, J., Shamian, J \& Wilk, P. (2003), Workplace Empowerment as a Predictor of Nurse Burnout in Restructured Healthcare Settings, Longwoods Review, 1(3), 1-13.

Lazarus, R.S. (1991). Emotion and Adaptation, Oxford University Press, Oxford.

Lim, B. T. \& Martin, L. (2017). The Effect of Inter-Organizational Justice Perceptions on Organizational Citizenship Behaviors in Construction Projects. International Journal of Project Management, 35(2), 95-106.

Lovell, S. E., Kahn, A. S., Anton, J., Davidson, A., Dowling, E., Post, D., \& Mason, C. (1999). Does Gender Affect the Link Between Organizational Citizenship Behavior and Preference Evaluation? Sex Roles, 41(5), 469-478.

Luthans, F (2011). Organizational Behavior: An Evidence-Based Approach, edisi 12, New York, NY: McGraw-Hill/Irwin, The McGraw-Hill Companies, Inc.

Makvandi, A., Farah, N., Behnam, M., Reza, P \& Parvin, E. (2017). Causal Model of Job Motivation with Organizational Citizenship Behavior (OCB) and the Mediating Role of Organizational Commitment in Teachers, Iranian journal of educational Sociology, $1 / 2$.

Matthews, G., Roberts, R.D. \& Zeidner, M. (2004). Seven myths about emotional intelligence, Psychological Inquiry, 15(3), 179-196.

Meyer, J.P. \& Allen, N.J. (1997). Commitment in the Workplace: Theory, Research Andapplication. Thousand Oaks, CA: SAGE

Meyer, J.P., \& Allen, N.J. (1991). A Three Component Conceptualization of Organizational Commitment. Human Resource Management Review, 1/1, 61-89.

Mayer, J. D., Salovey, P. 1997. The Intelligence of Emotional Intelligence. Intelligence, 17, 433-442.

Moorman, R.H. (1991). The Relationship between organizational justice and organizational citizenship behaviors: Do fairness perceptions influence employee citizenship? Journal of Applied Psychology, 76, 845-855.

Moorman, R. H., Blakely, G. L., \& Niehoff, B. P. (1998). Does Perceived Organizational Support Mediate the Relationship Between Procedural Justice and Organizational Citizenship Behavior? Academy of Management Journal, 41, 351-357.

Mortaza, Z \& Carol, F. (2019). Voice, creativity, and big five personality traits: A metaanalysis, Human Performance, 32(1), 30-51. 
Neal, M. A., Ronald, H. H \& Quy, N. H. (2016). Integrating Emotions and Affect in Theories of Management, Academy of Management Review, 42/2,

Nur Farhah, M. S \& Fatimah, W. H. (2018). The Influence of the Five Factor Personality Upon Organisational Citizenship Behaviour (OCB) Among Teachers, Jurnal Psikologi Malaysia, 32(2), 1-11.

O'Reily, C \& Chatman, J. (1996). Culture as social control corporation, cults and commitment, in Staw, B.M and Cummings, L.L. (Eds) Research in Organization Behavior, Vol 18, Elseiver Science/JAI Press, New York, NY, pp 157-200.

Organ, D. W. (1990). The Motivational Basis of Organizational Citizenship Behavior. Research in Organizational Behavior, 12, 43-72.

Organ, D.W. \& Ryan, K. (1995). A Meta-Analytic Review of Attitudinal and Dispositional Predictors of Organizational Citizenship Behavior, Personnel Psychology, 48(4), 775-800.

Organ, D.W., Podsakoff, P.M., \& Mackenzie, S.B. (2006). Organizational Citizenship Behavior: Its Nature, Antecedents and Consequences, Sage Publications.

Paramitha, D. P. (2014). Pengaruh Budaya Organisasi, Gaya Kepemimpinan dan Keadilan Organisasi Terhadap Organizational Citizenships Behavior (OCB) Dengan Kepuasan Kerja Dan Komitmen Organisasi Sebagai Variabel Mediasi Pada Karyawan Bni Kcu UGM Yogyakarta. (Tesis, tidak diterbitkan). Universitas Sebelas Maret Surakarta

Parul, A. (2018). Antecedents of Teacher's Organizational Citizenship Behaviors, GERA, Georgia Educational Research Association, Oktober/5.

Pooja, G, Renu, R \& Parul, M. (2019). Modelling the causal relationship between justice and citizenship behaviours: an Indian perspective, International. Journal. Indian Culture and Business Management, 18/1.

Puffer, S. (1987). Prosocial behavior, non-compliant behavior, and work performance among commission salespeople. Journal of Applied Psychology, 72, 615-621.

Purba, D. E \& Seniati, A. N. C. (2004). Pengaruh Kepribadian dan Komitmen Organisasi terhadap Organizational Citizenship Behavior. Makara, Sosial Humaniora, $8(3), 105-111$.

Rahmat, J. (1986), Psikologi Komunikasi, Bandung, Remadja Karya.

Rahmi, B. M. (2013). Pengaruh Kepemimpinan Tranformasional Terhadap Organizational Citizenship Behavior Dan Komitmen Organisasional Dengan Mediasi Kepuasan Kerja, Studi Pada Guru Tetap SMA Negeri Di Kabupaten Lombok Timur, (Tesis, Tidak di terbitkan), Pasca Sarjana, Universitas Udayana, Bali

Riana, S, Sampeadi \& Sunardi. (2018). Perbedaan Organizational Citizenship Behavior (Ocb), Kepuasan Kerja dan Stres Kerja Berdasarkan Gender Pada Perawat Instalasi 
Rawat Inap Rsd Balung Kabupaten Jember, isma Jurnal Bisnis dan Manajemen, 12(3), 331-340.

Riffat-un-Nisa, A, Ghazanfar, A \& Sobia, A. (2018). The Moderating Role of Gender in the Relationship among Organizational Justice, Commitment, Job Satisfaction and Organizational Citizenship Behaviors of Secondary School Teachers, Pakistan Journal of Education, 35(1), 97-112.

Robbin, S. P. \& Judge, T. (2013). Organizational Behavior, Edition 15, Upper Saddle River, New Jersey, Pearson.

Salwa \& Rinandita, W. (2017). Hubungan Kepribadian Big Five Terhadap Pembentukan Organizational Citizenship Behaviour (OCB) Pegawai Pada PT Amarta Karya (Persero) Bekasi, Jurnal Ilmiah Manajemen \& Bisnis, 18(2), 164-176.

Sambung \& Iring, (2014). Pengaruh Kepribadian Terhadap Organizational Citizenship Organization Dengan Komitmen Organisasi Sebagai Intervening (Studi Pada Universitas Palangka Raya). Jurnal Manajemen dan Akuntansi, 3(1), 1-16.

Sambung, R., Thoyib, A., Afnan, Eka. \& Surachman. (2012). Pengaruh Kepuasan Kerja, Komitmen Organisasional, Kepribadian Dan Profesionalisme Dosen Terhadap Organizational Citizenship Behavior Serta Dampaknya Terhadap Kinerja Dosen, Studi Pada Universitas Palangka Raya, Jurnal Aplikasi Manajemen, 10(1), 12 - 20.

Saptoani, A. (2011). Hubungan Antara Karakter, Kecerdasan Emosional, Soft Skill, Stress Kerja Dan Kepuasan Kerja Dengan Perilaku Kewargaan Organisasi (OCB) Tenaga Pendidik Di Lembaga Pendidikan Tni Angkatan Laut. (Disertasi, Tidak diterbitkan), Pasca Sarjana Universitas Negeri Malang.

Saraih, U. N., Zin Aris, A.Z., Karim. K. M \& Abu Samah, I. H (2017). Relationships between Organizational Commitment, OCB, Organizational Justice and Turnover Intention: Evidence from Educational Institution in Malaysia, Review of Integrative Business and Economics Research, 6(2), 64-77.

Schappe, S.P. (1998). The Influence of Job Satisfaction, Organizational Commitment, And Fairness Perceptions on Organizational Citizenship Behavior. Journal of Psychology. 132(3), $277-291$.

Schutte, N.S. \& Malouff, J.M. 2001, Emotional Intelligence mediates the relationship between mindfulness and subjective well-being. Personality and Individual Difference, 50(7), 1116-1119.

Seniati, L. (2006). Pengaruh Masa Kerja, Trait Kepribadian, Kepuasan Kerja, Dan Iklim Psikologis Terhadap Komitmen Dosen Pada Universitas Indonesia. Makara, Sosial Humaniora, 10(2), 88-97.

Shapiro, C, Jacqueline A-M. (2002). A Psychological Contract Perspective on Organizational Citizenship Behavior. Journal of organizational behavior, 23(8), 927 946. 
Shields, S. A., \& Warner, L. R. (2007). Gender and the emotion politics of emotional intelligence. In S. Fineman (Ed.), The emotional organisation: Passions and powers (pp. 167-183). London, UK: Blackwell.

Siti. H \& Harnoto, H. (2018). Role of Organizational Citizenship Behavior (OCB), Perception of Justice and Job Satisfaction on Employee Performance, Jurnal Dinamika Manajemen, 9(2), 170-178.

Sjahruddin, H. (2013). Organizational Justice, Organizational Commitment and Trust in Manager as Predictor of Organizational Citizenship Behavior. Interdisciplinary Journal of Contemporary Research in Business. 4/12

Smith, C. A., Organ, D. W., \& Near, J.P. (1983). Organizational Citizenship Behavior: It's Nature and Antecedent. Journal of Applied Psychology, 68(4), 653-663.

Sommers, S. M., Bae, S. H. \& Luthans, F. (1996). Organizational Commitment Across Cultures: The Impact of Antecedents on Korean Employees. Human Relation, 49(7), 977-993.

Soner, P. (2009). Organizational citizenship behavior (OCB) display levels of the teachers at secondary schools according to the perceptions of the school administrators. World Conference on Educational Sciences 2009. in Procedia Social and Behavioral Sciences, 1, 1591-1596.

Suci, R. N., Emmy, M \& Ferry, N. (2018). Perbedaan Organizational Citizenship Behavior (OCB) Ditinjau Dari Karakter Kepribadian Big-Five Dan Tipe Komitmen Organisasi, Jurnal RAP UNP, 9(1), 105-117.

Sudrajat, A. (2014). Nilai-nilai Budaya Gotomh Royong Etnik Betawi sebagai sumber pembelajaran IPS, (Disertasi, tidak diterbitkan), Sekolah Pasca Sarjana, Universitas Pendidikan Indonesia, Jakarta.

Su-Yung Fu. (2000). The Relationship among Transformational Leadership, Organizational Commitment and Citizenship Behavior: The Case of Expatriates. Master's Tesis. URN: etd-0201101-153856

Tuan, T. L. (2019). Building employees' organizational citizenship behavior for the environment: The role of environmentally-specific servant leadership and a moderated mediation mechanism, International Journal of Contemporary Hospitality Management, 31(1), 406-426.

Turnipseed. D. L. (2018). Emotional intelligence and OCB: The moderating role of work locus of control, The Journal of Social Psychology, 158(3), 322-336.

Tornblom, K. Y., \& Vermunt, R. (Eds.). (2000). Distributive and procedural justice. Aldershot: Ashgate.

Umar, H. 2001. Riset Sumber Daya Manusia dalam Organisasi. Jakarta, Pt. Gramedia Utama. 
Wayne, S. J., Shore, L. M., \& Liden, R. C. (1997). Perceived Organizational Support and Leader-Member Exchange: A Social Exchange Perspective. Academy of Management Journal, 40(1), 82-111.

Widyaningrum. (2010). Pengaruh Keadilan Organisasi Terhadap Kepuasan Kerja, Komitmen Organisasi Dan Organizational Citizenship Behavior Pegawai (Studi Kasus di Rumah Sakit Bersalin Pura Raharja Surabaya). Majalah Ekonomi. XX/1, 100-118.

Willis, A. (2018). Emotional and Spiritual Intelligence in the Workplace in Relation to Organizational Citizenship Behavior. A thesis, Master of Science in Psychology, Kaplan University.

Wong, C. Sum., Wong, P \& Law, K. (2004). Development and validation of a forced choice emotional intelligence measure for Chinese respondents in Hong Kong. Asia Pacific Journal of Management, 21(4), 535-559.

Yu, H., Jiunn-Horng, L, Cheng-Joo, E, Cheng-I, Y \& Li-Hung, L. (2018). Organizational Citizenship Behaviour of Men in Nursing Professions: Career Stage Perspectives. Collegian, 25(1), 19-26.

Zeinabadi, H., \& Salehi, K. (2011). Role of procedural justice, trust, job satisfaction, and organizational commitment in Organizational Citizenship Behavior (OCB) of teachers: proposing a modified social exchange model. Procedia - Social and Behavioral Sciences, 29, $1472-1481$.

Zhou, J, Paul, J. G. \& Gordon, B. (2017). Relationships between organizational justice, organizational trust and organizational commitment: a cross-cultural study of China, South Korea and Australia, The International Journal of Human Resource Management, 28(7), 973-1004. 